\title{
Analytical Modeling and Determination of the Characteristic Parameters of the Different Commercial Technologies of Photovoltaic Modules
}

\author{
Ahmed Sidibba1, Diene Ndiaye1, Menny El Bah², Sidi Bouhamady³ \\ ${ }^{1}$ Laboratory of Electronic, Computing, Telecommunication and Renewable Energies (LEITER), UGB, Saint-Louis, Senegal \\ ${ }^{2}$ Renewable Energy Unit, Department of Physics, University of Nouakchott Al-Aasriya, Nouakchott, Mauritania \\ ${ }^{3}$ Laboratory of Applied Energetics, Ecole Polytechnique of Dakar, Dakar, Senegal \\ Email: sidiabaahmed@gmail.com
}

How to cite this paper: Sidibba, A., Ndiaye, D., El Bah, M. and Bouhamady, S. (2018) Analytical Modeling and Determination of the Characteristic Parameters of the Different Commercial Technologies of Photovoltaic Modules. Journal of Power and Energy Engineering, 6, 14-27.

https://doi.org/10.4236/jpee.2018.63002

Received: February 20, 2018

Accepted: March 23, 2018

Published: March 26, 2018

Copyright (c) 2018 by authors and Scientific Research Publishing Inc. This work is licensed under the Creative Commons Attribution International License (CC BY 4.0).

http://creativecommons.org/licenses/by/4.0/

\begin{abstract}
This work presents a method of optimization of the photovoltaic generator (PV) based on the electrical model with a diode. The method consists of solving a second degree equation representing the derivative of the power function. The current and the maximum voltage being determined, the maximum power is deduced. Four popular types of photovoltaic panels from different manufacturers were considered for the study: BYD Model (BYD 320P6C-36), Atersa Grupo Model (A-320P GSE), SunPower Model (E19-320) and Model operated in the $50 \mathrm{MW}$ power plant of Nouakchott-Mauritania (JKM320PP-72-V) of JinkoSolar. A comparative study is carried out between the simulated results and the data of the manufacturer of different technologies. The results obtained prove the effectiveness of the proposed method and that the BYD 320P6C-36 model is the most efficient among the four different technologies studied.
\end{abstract}

\section{Keywords}

Model, Photovoltaic Generator, Power Function, Optimization, Maximum Power

\section{Introduction}

At present, we are witnessing: Rapid decline in fossil fuel reserves due to increased use of thermal power plants; Increased air pollution correlated with the burning of fossil fuels, which generates greenhouse gases. 
Therefore, in the current scenario, there is an urgent need to accelerate research and development of renewable energy technology, especially solar energy, to meet global energy demand. Solar energy applications have been progressively increasing worldwide. This is due to the decrease in the cost of photovoltaic panels with the increasing demand, and the increase in the duration of use (lifetime). Photovoltaic is very competitive in areas far away from the conventional grid [1]. However, its exploitation requires a well-optimized design and dimensioning. The performance and economic profitability of this type of technology depends on different parameters that characterize its mathematical model. A precise knowledge of these parameters makes it possible to predict the performance of photovoltaic solar cells [2]. The five parameters of interest in the equivalent circuit are the photocurrent $\left(I_{p v}\right)$, the series resistance $\left(R_{s}\right)$, the diode saturation current $\left(I_{o}\right)$, the parallel resistance $\left(R_{s h}\right)$ and the ideality factor $(n)$. The voltage-current relationship of a solar cell is described by a mathematical equation [3]. These various parameters make it possible to describe the behavior of the module and predict its performance. The models and methods used to evaluate these parameters have been the subject of several studies. Soto et al. (2006) [4] studied a five-parameter model using only manufacturer-supplied data with semi-empirical equations to predict the I-V and P-V curve of the cell for any operating condition and compared with experimental data from a Building integrated photovoltaic system for four different cellular technologies (mono-crystalline, multi-crystalline, silicon thin film and triple junction amorphous). They showed that the five-parameter model can be a precise tool for predicting energy production for single-junction cell types. Ould Mohamed Yahya et al. (2008) [5] also studied a five-parameter simulation model to predict the performance of a photovoltaic (PV) system operating in the meteorological conditions of the installation site and validated the simulation model from the experimental data of an individual $1.2 \mathrm{kWp}$ system installed in Nouakchott, Mauritania. R. Merahi et al. (2010) [6] used the four-parameter model to simulate the operation of the PV module (PW500 of PHOTOWATT) for different conditions of sunshine and temperature. They found that the increase in series resistance and the quality factor is due to the degradation of $\mathrm{I}(\mathrm{V})$ curve at the elbow. Dongue et al. (2012) [7] investigated the performance of the four- and five-parameter models used to predict the electrical response of multi-crystalline Shell SP75 and GES-P70 mono-crystalline PV modules for different operating conditions. They concluded that the four- and five-parameter models accurately adjust the experimental data of the two PV modules used for various operating conditions analyzed. Zerdoudi et al. (2015) [8] modeled a photovoltaic generator using the four-parameter model to simulate the operation of the PV model (SPR315 E) for different conditions of sunshine and temperature. The aim of this work is to characterize and modelisize four different commercial photovoltaic modules technologies and to study the efficiency of the method compared to different photovoltaic module technologies by using the average absolute relative error between the values simulated by the model and those given by the manu- 
facturers.

\section{Models and Methods}

\subsection{Models}

There are several commercial models of photovoltaic technologies that have certain performances depending on their location. Among these different technologies, the most exploited in Mauritania [9] are listed in Table 1. The data in Table 1 were obtained under standard test conditions $\left(G=1000 \mathrm{~W} / \mathrm{m}^{2}\right.$ and $T=$ $25^{\circ} \mathrm{C}$ ) according to the manufacturers of each technology.

\subsection{Method}

In the literature, there are two main models of photovoltaic electric generators; namely one and two diode models, with three or more parameters. In this work, a one diode photovoltaic module with five parameters whose equivalent diagram is presented in Figure 1 is studied. The five parameters here are: $I_{p h}, R_{s}, R_{s h}$, $I_{0}$ and $n[10]$ [11].

The current produced by the generator is obtained from Kirchhoff's laws as follows:

$$
I=I_{p h}-I_{D}-I_{s h}
$$

The diode current can be obtained through Shockley equation as follows [12]:

$$
I_{D}=I_{0} \cdot\left(\mathrm{e}^{\left(\frac{q(V+I R s)}{n N k T_{c}}\right)}-1\right)
$$

While the shunt current is given by the relation:

\begin{tabular}{|c|c|c|c|c|}
\hline Manufacturer & BYD [22] & Atersa Grupo [23] & SunPower [24] & JinkoSolar [25] \\
\hline Model & BYD 320P6C-36 & A-320P GSE & E19-320 & JKM320PP-72-V \\
\hline Peak power $P_{m}(\mathrm{Wc})$ & 320 & 320 & 320 & 320 \\
\hline Power tolerance (\%) & $0-5 \%$ & $\pm 1.5 \%$ & $+5 /-0 \%$ & $\pm 3 \%$ \\
\hline Maximum power voltage $V_{m p}(\mathrm{~V})$ & 36.78 & 37 & 54.7 & 37.4 \\
\hline Maximum power current $I_{m p}$ (A) & 8.7 & 8.65 & 5.86 & 8.56 \\
\hline Open circuit voltage $V_{c o}(\mathrm{~V})$ & 46.39 & 45.5 & 64.8 & 46.4 \\
\hline Short circuit current $I_{s c}$ (A) & 9.15 & 9.17 & 6.24 & 9.05 \\
\hline Module efficiency (\%) & 16.5 & 16.49 & 19.8 & 16.49 \\
\hline Temperature coefficients of $V_{c o} \mu_{V_{o c}}\left(\% /{ }^{\circ} \mathrm{C}\right)$ & -0.31 & -0.33 & -0.176 & -0.30 \\
\hline Temperature coefficients of $P_{m} \mu_{P_{m}} \quad\left(\% /{ }^{\circ} \mathrm{C}\right)$ & -0.39 & -0.43 & -0.38 & -0.40 \\
\hline Temperature coefficients of $I_{s c} \mu_{I_{s c}}\left(\% /{ }^{\circ} \mathrm{C}\right)$ & 0.07 & 0.05 & 0.035 & 0.06 \\
\hline NOCT (Nominal operating cell temperature) $\left({ }^{\circ} \mathrm{C}\right)$ & $45 \pm 2$ & $45 \pm 2$ & $45 \pm 2$ & $45 \pm 2$ \\
\hline Number of cells & 72 & 72 & 96 & 72 \\
\hline Area $\left(\mathrm{m}^{2}\right)$ & 1.94 & 1.94 & 1.63 & 1.94 \\
\hline
\end{tabular}

Table 1. Electrical characteristics of photovoltaic modules used. 


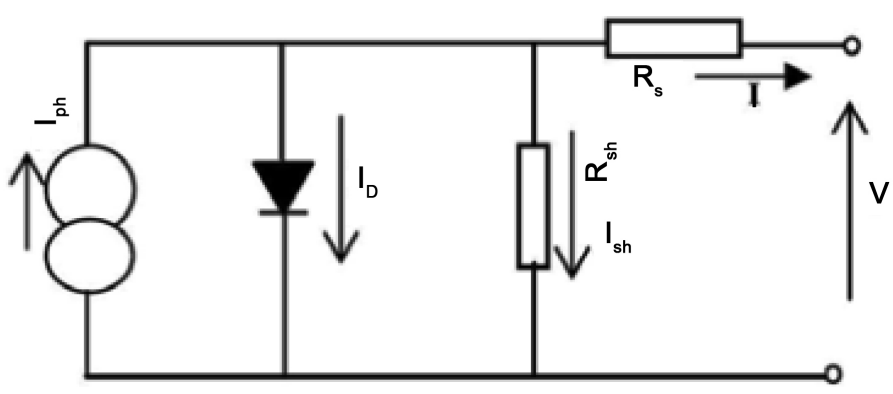

Figure 1. Electrical model of a PV generator with five parameters [4].

$$
I_{s h}=\frac{\left(V+I R_{s}\right)}{R_{s h}}
$$

Replacing (2) and (3) into (1) give the photovoltaic current as:

$$
I=I_{p h}-I_{0} \cdot\left(\mathrm{e}^{\left(\frac{q(V+I R s)}{n N k T_{c}}\right)}-1\right)-\frac{\left(V+I R_{s}\right)}{R_{s h}}
$$

If we assume that the parallel resistance $R_{\text {sh }}$ is very large (case of crystalline silicon) [13].

For this purpose Equation (4) becomes as follows:

$$
I=I_{p h}-I_{0} \cdot\left(\mathrm{e}^{\left(\frac{q(V+I R s)}{n N k T_{c}}\right)}-1\right)
$$

\section{Determination of the PV Generator Parameters}

1) Evaluation of $I_{p h}$

The light current $I_{p h}$ depends on both irradiance and temperature. It is given by [12] [14]:

$$
I_{p h}=\left[I_{s c}+\alpha\left(T_{c}-T_{r}\right)\right] \cdot\left(\frac{G}{G_{r}}\right)
$$

2) Evaluation of $I_{0}$

The reverse saturation current depending of cells temperature is given as follows [15] [16]:

$$
I_{0}=I_{\text {on }} \cdot\left(\frac{T_{c}}{T_{r}}\right)^{3} \cdot \mathrm{e}^{\left[\frac{q E_{g}\left(\frac{1}{T_{r}}-\frac{1}{T_{c}}\right)}{n k}\right]}
$$

At the open circuit voltage $I=0, V=V_{o c}$ and $I=0, V=V_{o c}$

$$
0=I_{s c}-I_{0 n} \cdot\left(\mathrm{e}^{\left(\frac{q V_{o c}}{n N k T_{c}}\right)}-1\right)
$$

So the nominal saturation current is obtained through:

$$
I_{0 n}=\frac{I_{s c}}{\mathrm{e}^{\left(\frac{q V_{o c}}{n k N T_{c}}\right)}-1}
$$


By replacing the Equation (9) into Equation (7) one gets:

$$
I_{0}=\frac{I_{s c}}{\mathrm{e}^{\left(\frac{q V_{o c}}{n k N T_{c}}\right)}-1} \cdot\left(\frac{T_{c}}{T_{r}}\right)^{3} \cdot \mathrm{e}^{\left[\frac{q E_{g}\left(\frac{1}{T_{r}}-\frac{1}{T_{c}}\right)}{n k}\right]}
$$

3) Evaluation of $R_{s}$

Various techniques have been used to determine the series resistance $R_{s}$ [3] [17]. In this work the series resistance is evaluated as follows:

$$
R_{s}=\left(-\left.\frac{\mathrm{d} V}{\mathrm{~d} I}\right|_{V=V_{o c}}\right)
$$

Considering the asymptotic behavior of the I-V curve under short-circuit and open-circuit conditions $R_{s}$ can be calculated as [18]:

$$
R_{s}=\frac{\frac{N_{s} n k T_{c}}{q} \cdot \ln \left(1-\frac{I_{m p}}{I_{s c}}\right)+V_{o c}-V_{m p}}{I_{m p}}
$$

4) Evaluation of $n$ :

At the short circuit point, $I=I_{s c}, V=0$ :

$$
I_{s c}=I_{p h, r e f}-I_{0, r e f} \cdot\left(\mathrm{e}^{\left(\frac{q R_{s} I_{S c}}{n N k T_{c}}\right)}-1\right)
$$

At the maximum power point, $I=I_{m p}, V=V_{m p}$ :

$$
I_{m p}=I_{p h, r e f}-I_{0, r e f} \cdot\left(\mathrm{e}^{\left(\frac{q\left(V_{m p}+I_{m p} R_{s}\right)}{n N k T_{c}}\right)}-1\right)
$$

The reverse saturation current Io for any diode is a very small quantity, on the order of $10^{-5}$ or $10^{-6} \mathrm{~A}$ [19]. This minimizes the impact of the exponential term in Equation (13), so it is safe to assume that the photocurrent equals the short-circuit current [20]. Another simplification [21] can be made regarding the first term in Equations (8) and (14). In both cases, regardless of the system size, the exponential term is much greater than the first term. For this reason the first term can be neglected. Then, the equation system becomes:

$$
\begin{gathered}
I_{s c} \approx I_{p h, r e f} \\
0=I_{s c}-I_{0, r e f} \cdot\left(\mathrm{e}^{\left(\frac{q V_{o c}}{n N k T_{r}}\right)}-1\right) \\
\left.I_{m p}=I_{p h, r e f}-I_{0, \text { ref }} \cdot \mathrm{e}^{\left(\frac{q\left(V_{m p}+I_{m p} R_{s}\right)}{n N k T_{r}}\right)}\right)
\end{gathered}
$$

Combining (16) and (17), the ideality factor is evaluated as follows:

$$
n=\frac{q\left(2 V_{m p}-V_{o c}\right)}{N k T_{r}\left(\frac{I_{m p}}{I_{s c}-I_{m p}}+\ln \left(\frac{I_{s c}-I_{m p}}{I_{s c}}\right)\right)}
$$




\subsection{Maximum Power Point Determination}

By using the expression of the PV current defined by Equation (5), the voltage supplied by the generator is:

$$
V=\frac{n N K T_{c}}{q} \ln \left(1+\frac{I_{p h}-I}{I_{o}}\right) \cdot R_{s} I
$$

The electric power produced by the generator is given by:

$$
P=V \cdot I
$$

By replacing (19) into (20) one obtain,

$$
P=\frac{n N K T_{c}}{q} \ln \left(1+\frac{I_{p h}-I}{I_{o}}\right) \cdot R_{s} I^{2}
$$

From the function $P=f(I)$, the extremum is obtained by the resolution of the equation

$$
\begin{gathered}
\frac{\mathrm{d} P}{\mathrm{~d} I}=0 \\
2 R_{s} I^{2}-\left[C \ln \left(1+\frac{I_{p h}-I}{I_{o}}\right)+C+2 R_{s}\left(I_{o}+I_{p h}\right)\right] \cdot I \\
+C \ln \left(1+\frac{I_{p h}-I}{I_{o}}\right)\left(I_{o}+I_{p h}\right)=0
\end{gathered}
$$

In the above Equation (22),

$$
C=\frac{n N k T_{c}}{q}
$$

The limit development near of $I=0$, in one order for $\ln \left(1+\frac{I_{p h}-I}{I_{o}}\right)$ is given by:

$$
\ln \left(1+\frac{I_{p h}-I}{I_{o}}\right)=\ln \left(1+\frac{I_{p h}}{I_{o}}\right)-\frac{I}{I_{p h}+I_{o}}
$$

By replacing Equation (24) into Equation (22), one can have:

$$
\begin{aligned}
& 2 R_{s} I^{2}-\left[C \ln \left(1+\frac{I_{p h}}{I_{o}}\right)-\frac{C I_{o}}{I_{p h}+I_{o}}+C+2 R_{s}\left(I_{o}+I_{p h}\right)\right] \cdot I \\
& +C \ln \left(1+\frac{I_{p h}}{I_{o}}\right)\left(I_{o}+I_{p h}\right)-\frac{C I\left(I_{o}+I_{p h}\right)}{I_{p h}+I_{o}}=0
\end{aligned}
$$

By rearranging Equation (25), one can obtain the equation of the second degree (26) below:

$$
\begin{aligned}
& \left(C+2 R_{s}\left(I_{o}+I_{p h}\right)\right) I^{2}-\left(I_{o}+I_{p h}\right)\left[C \ln \left(1+\frac{I_{p h}}{I_{o}}\right)+2 C+2 R_{s}\left(I_{o}+I_{p h}\right)\right] I \\
& +C \ln \left(1+\frac{I_{p h}}{I_{o}}\right)\left(I_{o}+I_{p h}\right)^{2}
\end{aligned}
$$


To solve this equation of the second degree let's put:

$$
\begin{gathered}
X_{1}=\left(C+2 R_{s}\left(I_{o}+I_{p h}\right)\right) \\
X_{2}=\left(I_{o}+I_{p h}\right)\left[C \ln \left(1+\frac{I_{p h}}{I_{o}}\right)+2 C+2 R_{s}\left(I_{o}+I_{p h}\right)\right] \\
X_{3}=C \ln \left(1+\frac{I_{p h}}{I_{o}}\right)\left(I_{o}+I_{p h}\right)^{2}
\end{gathered}
$$

The Equation (26) could be rewritten as follows:

$$
X_{1} I^{2}+X_{2} I+X_{3}=0
$$

The resolution of Equation (30) permits to obtain the following solutions:

$$
\begin{gathered}
I_{\text {max }}=\frac{-X_{2} \pm \sqrt{X_{2}^{2}-4 X_{1} X_{3}}}{2 X_{1}} \\
V_{\text {max }}=\frac{n N K T_{c}}{q} \ln \left(1+\frac{I_{p h}-I_{\text {max }}}{I_{o}}\right) \cdot R_{s} I_{\text {max }} \\
P_{\text {max }}=V_{\text {max }} \cdot I_{\text {max }}
\end{gathered}
$$

$I_{\max }, V_{\max }$ and $P_{\max }$ are respectively the maximum current, the maximum voltage and the maximum power.

\section{Results and Discussion}

The accuracy of the modeling methods described in this work is validated by experimental data published by the manufacturers of the selected PV modules. Four modules of different technologies are used for the verification. These include: the BYD model (BYD 320P6C-36), the Atersa Grupo model (A-320P GSE), the SunPower model (E19-320) and the model operated in the $50 \mathrm{MW}$ Nouakchott power station $\left(15.983^{\circ} \mathrm{W}, 18.1553^{\circ} \mathrm{N}\right)$ in Mauritania

(JKM320PP-72-V) of JinkoSolar. The experimental data $(I, V)$ are extracted from the data sheets [22] [23] [24] [25] for the different technologies studied. Table 2 presents the results of these unknown parameters of these different commercial technologies under standard conditions $\left(T=25^{\circ} \mathrm{C}\right.$ and $\left.G=1000 \mathrm{~W} / \mathrm{m}^{2}\right)$.

The values of the parameters calculated using the method proposed in this work are compatible with the literature [4] [5] [6] [7] [8].

The determination of these parameters in parallel with the exploitation of the

Table 2. Unknown parameters of STC modules $\left(T=25^{\circ} \mathrm{C}\right.$ and $\left.G=1000 \mathrm{~W} / \mathrm{m}^{2}\right)$.

\begin{tabular}{ccccc}
\hline Parameters & BYD 320P6C-36 & A-320P GSE & E19-320 & JKM320PP-72-V \\
\hline$I_{p h}(\mathrm{~A})$ & 9.15 & 9.17 & 6.24 & 9.05 \\
$I_{o}(\mathrm{~A})$ & $7.2298 \times 10^{-12}$ & $2.6219 \times 10^{-9}$ & $6.7684 \times 10^{-8}$ & $4.2692 \times 10^{-10}$ \\
$R_{s}(\Omega)$ & 0.5282 & 0.2957 & 0.0361 & 0.3866 \\
$R_{s h}(\Omega)$ & $+\infty$ & $+\infty$ & $+\infty$ & $+\infty$ \\
$n$ & 0.9003 & 1.1197 & 1.4331 & 1.0553 \\
\hline
\end{tabular}


proposed method made it possible to obtain the optimal parameters of various technologies which are: the open circuit voltage, the maximum power, the short-circuit current. The results of these parameters are shown in Table 3.

Figures 2-9 show the I-V and P-V curves for the different photovoltaic module technologies used under the standard test conditions $\left(T=25^{\circ} \mathrm{C}\right.$ and $G=$ $1000 \mathrm{~W} / \mathrm{m}^{2}$ ).

Table 3. Optimal parameters of STC modules $\left(T=25^{\circ} \mathrm{C}\right.$ and $\left.G=1000 \mathrm{~W} / \mathrm{m}^{2}\right)$.

\begin{tabular}{ccccc}
\hline Parameters & BYD 320P6C-36 & A-320P GSE & E19-320 & JKM320PP-72-V \\
\hline$I_{s c}(\mathrm{~A})$ & 9.15 & 9.17 & 6.24 & 9.05 \\
$V_{\text {oc }}(\mathrm{V})$ & 46.39 & 45.5 & 64.8 & 46.4 \\
$P_{\max }(\mathrm{W})$ & 319.9150 & 319.9472 & 320.4132 & 320.0529 \\
$V_{\max }(\mathrm{V})$ & 36.5999 & 36.7724 & 54.3209 & 37.1864 \\
$I_{\max }(\mathrm{A})$ & 8.7409 & 8.7007 & 5.8985 & 8.6067 \\
\hline
\end{tabular}

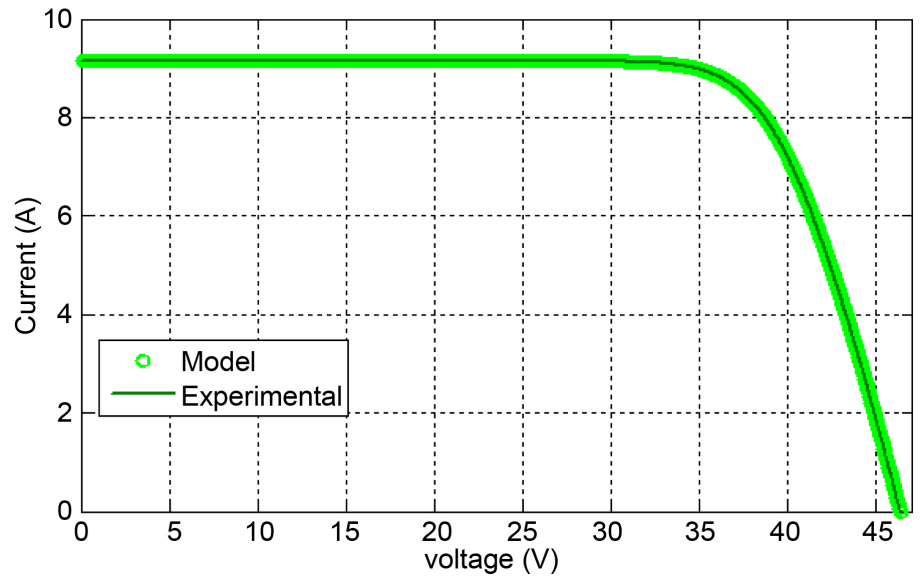

Figure 2. Characteristic I(V) for BYD 320P6C-36 at $T=25^{\circ} \mathrm{C}$ and $G=$ $1000 \mathrm{~W} / \mathrm{m}^{2}$. A comparison between the experimental values and the calculated values.

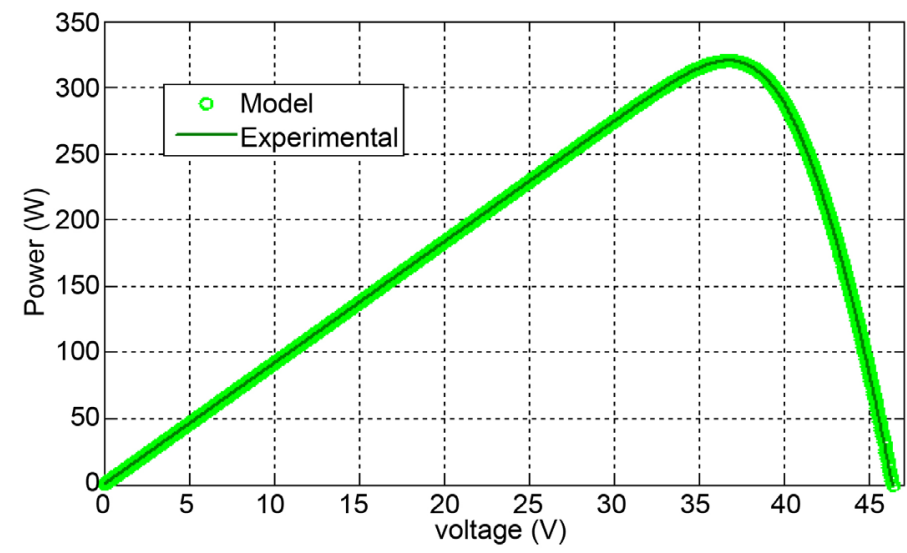

Figure 3. Characteristic $\mathrm{P}(\mathrm{V})$ for BYD $320 \mathrm{P} 6 \mathrm{C}-36$ at $T=25^{\circ} \mathrm{C}$ and $G=$ $1000 \mathrm{~W} / \mathrm{m}^{2}$. A comparison between the experimental values and the calculated values. 


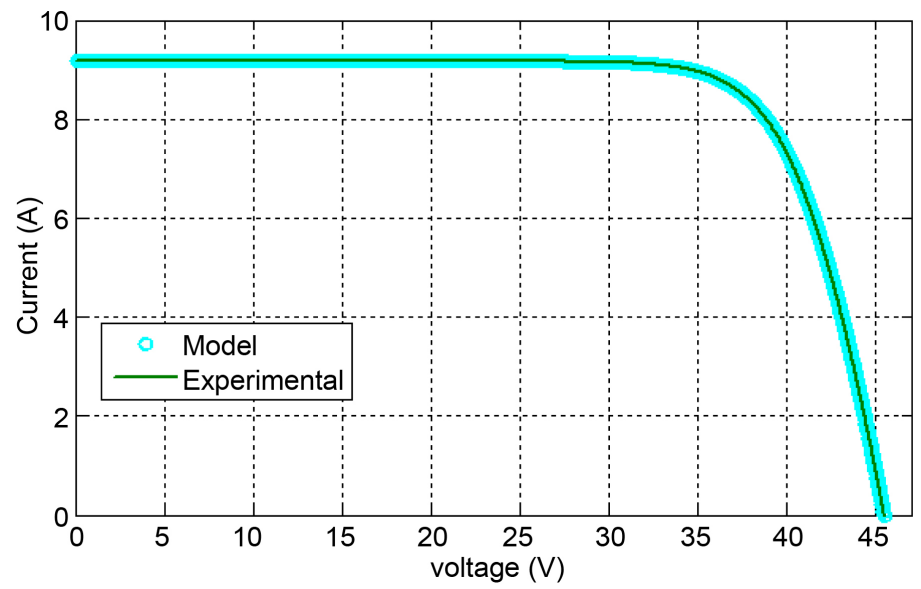

Figure 4. Characteristic I(V) for A-320P GSE at $T=25^{\circ} \mathrm{C}$ and $G=$ $1000 \mathrm{~W} / \mathrm{m}^{2}$. A comparison between the experimental values and the calculated values.

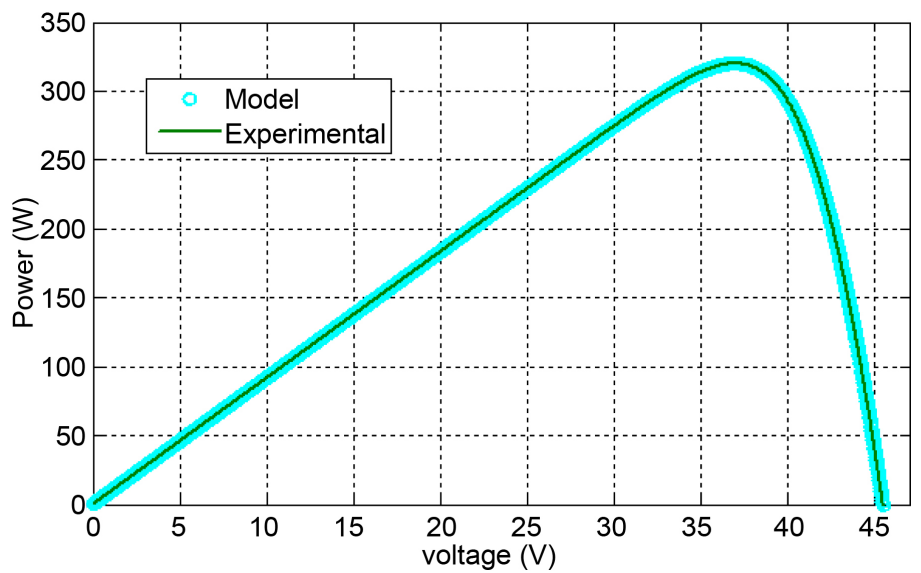

Figure 5. Characteristic $\mathrm{P}(\mathrm{V})$ for A-320P GSE at $T=25^{\circ} \mathrm{C}$ and $G=$ $1000 \mathrm{~W} / \mathrm{m}^{2}$. A comparison between the experimental values and the calculated values.

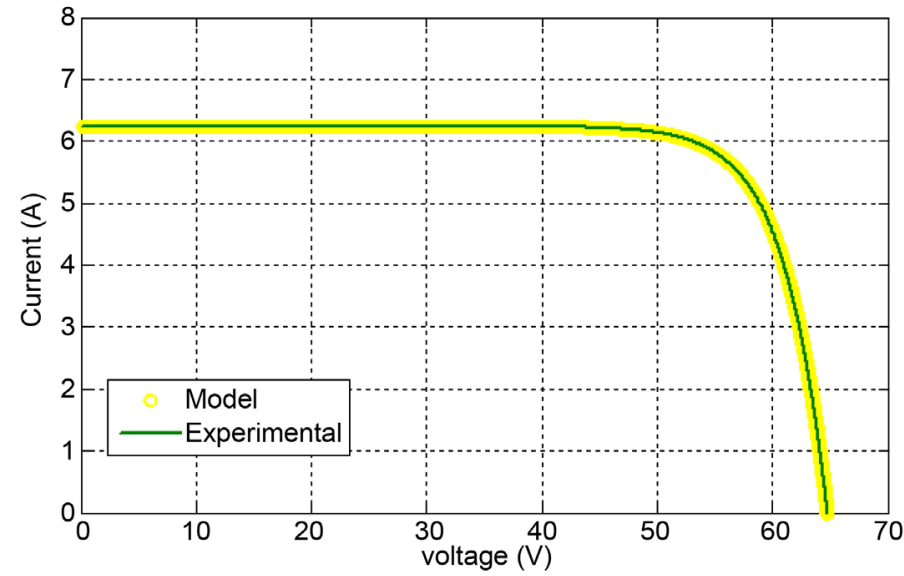

Figure 6. Characteristic I(V) for E19-320 at $T=25^{\circ} \mathrm{C}$ and $G=1000$ $\mathrm{W} / \mathrm{m}^{2}$. A comparison between the experimental values and the calculated values. 


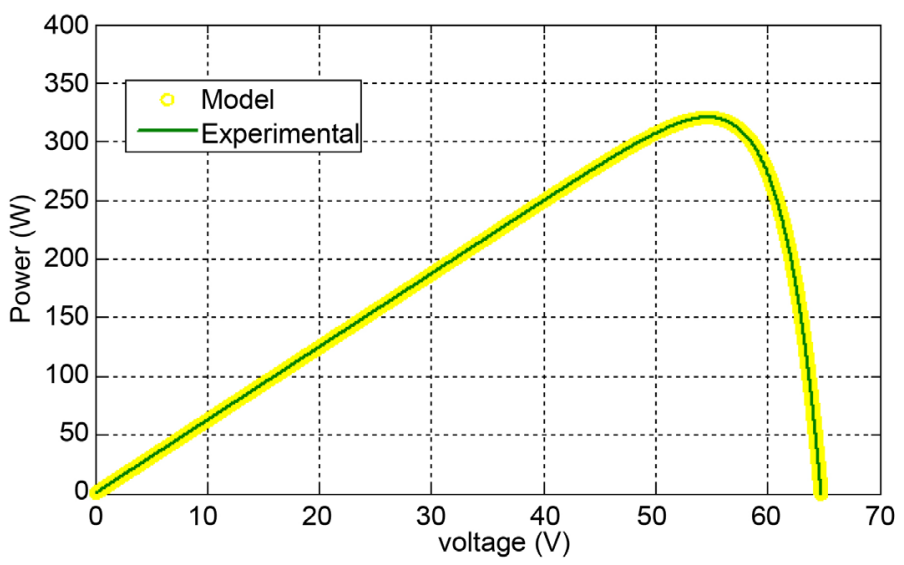

Figure 7. Characteristic $\mathrm{P}(\mathrm{V})$ for $\mathrm{E} 19-320$ at $T=25^{\circ} \mathrm{C}$ and $G=1000$ $\mathrm{W} / \mathrm{m}^{2}$. A comparison between the experimental values and the calculated values.

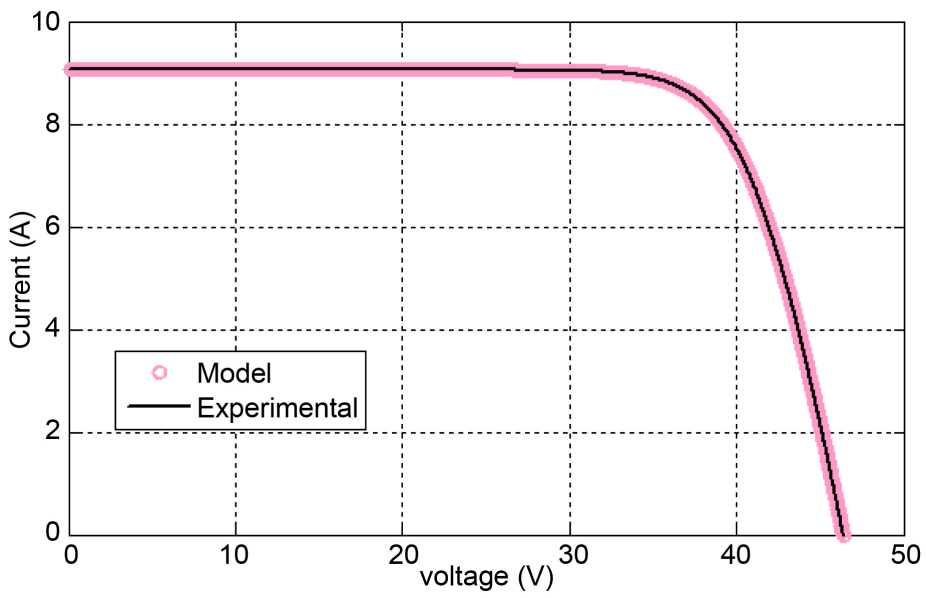

Figure 8. Characteristic I(V) for JKM320PP-72-V at $T=25^{\circ} \mathrm{C}$ and $G=$ $1000 \mathrm{~W} / \mathrm{m}^{2}$. A comparison between the experimental values and the calculated values.

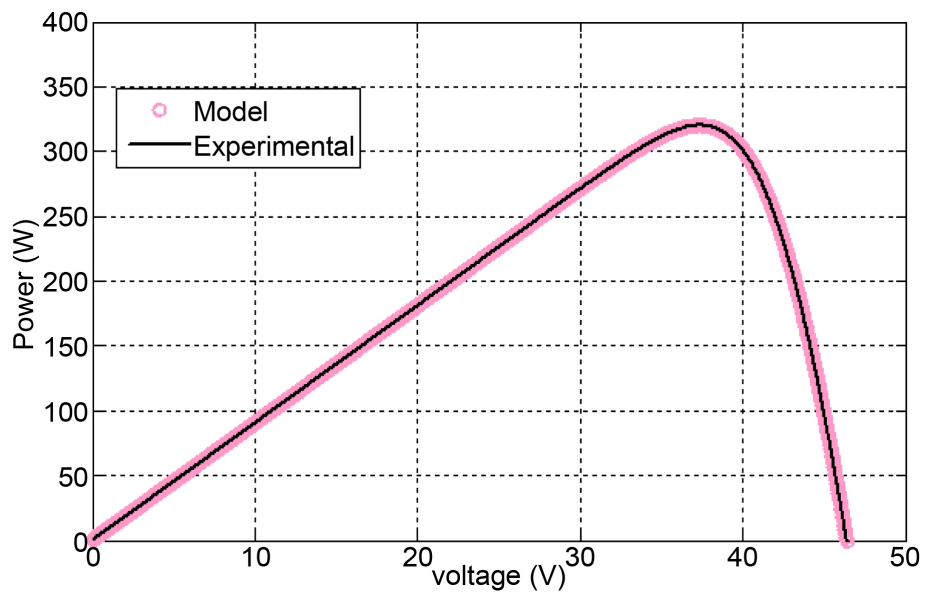

Figure 9. Characteristic $\mathrm{P}(\mathrm{V})$ for JKM320PP-72-V at $T=25^{\circ} \mathrm{C}$ and $G=$ $1000 \mathrm{~W} / \mathrm{m}^{2}$. A comparison between the experimental values and the calculated values. 
These figures show a consistency between the experimental results and the expected results. We note that the calculated values are in good agreement with the experimental values provided by the manufacturers.

In order to quantify the quality of the modeling procedure for the I-V characteristics of different PV module technologies, the performance parameter is used to compare the values simulated by the method and the values given by the manufacturers of different technologies. This parameter is the average absolute relative error. It is defined as following:

$$
E_{x}=\frac{x_{i}-X_{m i}}{X_{m i}} \cdot 100
$$

$x_{i}$ and $x_{m i}$ are the theoretical value given by the method and the measured value given by the manufacturer, respectively.

The results of comparisons between the simulations and the manufacturer's data using four photovoltaic module technologies under standard test conditions $\left(T=25^{\circ} \mathrm{C}\right.$ and $\left.G=1000 \mathrm{~W} / \mathrm{m}^{2}\right)$ are shown in Table 4 .

The results obtained prove the precision of the modeling method with an average absolute relative error between the estimated power and the measured power is less than $0.035 \%$ and that BYD 320P6C-36 technology is the most efficient among the four different PV module technologies studied with the average absolute relative error for the maximum point current is $0.46 \%, 0.51 \%$ for the maximum point voltage and $0.021 \%$ for the maximum point power.

Table 4. Mean absolute relative error between simulated values and values provided by the manufacturers.

\begin{tabular}{|c|c|c|c|c|c|}
\hline Parameters & $I_{s c}(\mathrm{~A})$ & $V_{o c}(\mathrm{~V})$ & $I_{\text {max }}(\mathrm{A})$ & $V_{\text {max }}(\mathrm{V})$ & $P_{\max }(\mathrm{W})$ \\
\hline \multicolumn{6}{|l|}{ BYD 320P6C-36 } \\
\hline Measured values & 9.15 & 46.39 & 8.7 & 36.78 & 319.98 \\
\hline Calculated values & 9.15 & 46.39 & 8.74 & 36.59 & 319.91 \\
\hline$E_{x}$ & 0 & 0 & 0.46 & 0.51 & 0.021 \\
\hline \multicolumn{6}{|l|}{ A-320P GSE } \\
\hline Measured values & 9.17 & 45.5 & 8.65 & 37 & 320.05 \\
\hline Calculated values & 9.17 & 45.5 & 8.7 & 36.77 & 319.94 \\
\hline$E_{x}$ & 0 & 0 & 0.57 & 0.62 & 0.034 \\
\hline \multicolumn{6}{|l|}{ E19-320 } \\
\hline Measured values & 6.24 & 64.8 & 5.86 & 54.7 & 320.524 \\
\hline Calculated values & 6.24 & 64.8 & 5.8985 & 54.3209 & 320.4132 \\
\hline$E_{x}$ & 0 & 0 & 0.6570 & 0.6931 & 0.0346 \\
\hline \multicolumn{6}{|l|}{ JKM320PP-72-V } \\
\hline Measured values & 9.05 & 46.4 & 8.56 & 37.4 & 320.144 \\
\hline Calculated values & 9.05 & 46.4 & 8.6067 & 37.1864 & 320.0529 \\
\hline$E_{x}$ & 0 & 0 & 0.5456 & 0.5711 & 0.0285 \\
\hline
\end{tabular}




\section{Conclusion}

This paper focuses on the characterization and modeling of various commercial solar photovoltaic module technologies most used in Mauritania through an analytical modeling method to describe its behavior under conditions of use in the Sahel. The modeling data of these different technologies were taken from the data sheets of different manufacturers. Four types of technologies, namely: BYD 320P6C-36, A-320P GSE, E19-320 and JKM320PP-72-V were studied and compared according to the maximum power current, the maximum power voltage and the power maximum. The results obtained prove the precision of the modeling method with an average absolute relative error between the estimated power and the measured power is less than $0.035 \%$. The comparison results of these different technologies show that BYD 320P6C-36 technology is the most efficient among the four different PV module technologies studied with the average absolute relative error for maximum point current is $0.46 \%, 0,51 \%$ for the maximum point voltage and $0.021 \%$ for the maximum point power.

\section{Acknowledgements}

The authors express their gratitude to the African Center of Excellence in Mathematics, Computer Science and ICT (CEA-MITIC) for their financial grant.

\section{References}

[1] Hill, R. (1999) Prospects for Photovoltaic. Energy World, 208, 8-11.

[2] Sera, D., Teodorescu, R. and Rodriguez, P. (2007) PV Panel Model Based on Datasheet Values. IEEE International Symposium on Industrial Electronics, ISIE 2007, Vigo, 4-7 June 2007, 2392-2396. https://doi.org/10.1109/ISIE.2007.4374981

[3] Bashahuand, M. and Habyarimana, A. (1995) Review and Test of Methods for Determination of the Solar Cell Series Resistance. Renewable Energy, 6, 129-138. https://doi.org/10.1016/0960-1481(94)E0021-V

[4] De Soto, W., Klein, S.A. and Beckman, W.A. (2006) Improvement and Validation of a Model for Photovoltaic Array Performance. Solar Energy, 80, 78-88. https://doi.org/10.1016/j.solener.2005.06.010

[5] Ould Mohamed Yahya, A., Ould Mahmoud, A. and Youm, I. (2008) Etude et modélisation d'un générateur photovoltaïque. Revue des Energies Renouvelables, 11, 473-483.

[6] Merahi, R., Chenni, R. and Houbes, M. (2010) Modélisation et Simulation d'un Modèle PV par Matlab. $10^{\text {ème }}$ Séminaire International sur la Physique Energétique. Journal of Scientific Research, 1, 170.

[7] Dongue, S.B., Njomo, D., Tamba, J.G. and Ebengai, L. (2012) Modeling of Electrical Response of Illuminated Crystalline Photovoltaic Modules Using Four- and Five-Parameter Models. International Journal of Emerging Technology and Advanced Engineering, 2, 612-619.

[8] Kalu, C., Isaac A, E. and Anthony, U.M. (2016) Comparative Study of Performance of Three Different Photovoltaic Technologies. Mathematical and Software Engineering, 2, 19-29.

[9] Kety, K., Amou, K.A., Sagna, K., Tepe, K., Lare, Y. and Napo, K. (2016) Modélisa- 
tion et simulation d'un générateur photovoltaïque: Cas du module polycristallin Ecoline LX-260P installé au dispensaire de Sévagan (Togo). Revue des Energies Renouvelables, 19, 633-645.

[10] Zieba Falama, R., Dadjé, A., Djongyang, N. and Doka, S.Y. (2016) A New Analytical Modeling Method for Photovoltaic Solar Cells Based on Derivative Power Function. Journal of Fundamental and Applied Sciences, 8, 426-437. https://doi.org/10.4314/jfas.v8i2.17

[11] Aoun, N., Chenni, R., Nahman, B. and Bouchouicha, K. (2014) Evaluation and Validation of Equivalent Five-Parameter Model Performance for Photovoltaic Panels Using Only Reference Data. Energy and Power Engineering, 6, 235-245. https://doi.org/10.4236/epe.2014.69021

[12] Kong, K.C., bin Mama, M., Ibrahim, M.Z. and Muzathik, A.M. (2012) New Approach on Mathematical Modeling of Photovoltaic Solar Panel. Applied Mathematical Sciences, 6, 381-401.

[13] Tahri, K. and Benyoucef, B. (2010) Etude de Modélisation d'un Générateur Photovoltaïque. $10^{\mathrm{ème}}$ séminaire International sur la Physique Energétique. Journal of Scientific Research, 1, 192.

[14] Xiao, W., Dunford, W.G. and Capel, A. (2014) A Novel Modeling Method for Photovoltaic Cells. 35th Annual IEEE Power Electronics Specialists Conference, Aachen, 20-25 June 2004, 1950-1956.

[15] Zerdoudi, A. and Chenni, R. (2015) Etude de l'influence des différents paramètres sur un module photovoltaïque. Sciences \& Technologie A, 41, 49-54.

[16] Meflah, A., Rahmoun, K., Mahrane, A. and Chikh, M. (2017) Outdoor Performance Modeling of Three Different Silicon Photovoltaic Module Technologies. International Journal of Energy and Environmental Engineering, 8, 143-152. https://doi.org/10.1007/s40095-017-0228-6

[17] Chan, D. and Phang, J. (1987) Analytical Methods for the Extraction of Solar-Cell Single- and Double-Diode Model Parameters from I-V Characteristics. IEEE Transactions on Electron Devices, 34, 286-293. https://doi.org/10.1109/T-ED.1987.22920

[18] Khezzar, R., Zereg, M. and Khezzar, A. (2014) Modeling Improvement of the Four Parameter Model for Photovoltaic Modules. Solar Energy, 110, 452-454. https://doi.org/10.1016/j.solener.2014.09.039

[19] Chenni, R., Makhlouf, M., Kerbache, T. and Bouzid, A. (2007) A Detailed Modeling Method for Photovoltaic Cells. Energy, 32, 1724-1730.

https://doi.org/10.1016/j.energy.2006.12.006

[20] Bryan, F. (1999) Simulation of Grid-Tied Building Integrated Photovoltaic Systems. MS Thesis, Solar Energy Laboratory, University of Wisconsin, Madison. http://digital.library.wisc.edu/1793/7704

[21] Eckstein, J.H. (1990) Detailed Modeling of Photovoltaic Components. MS Thesis, Solar Energy Laboratory, University of Wisconsin, Madison. http://digital.library.wisc.edu/1793/45596

[22] http://www.byd.com

[23] http://www.enfsolar.com

[24] http://www.Sunpowercorp.com

[25] http://www.jinkosolar.com 


\section{Nomenclature}

\begin{tabular}{|c|c|c|c|}
\hline$I$ & Cell current (A) & $T_{c}$ & Cell Temperature (Kelvin) \\
\hline$V$ & Cell Voltage (V) & $T_{r}$ & Cell Temperature at reference condition \\
\hline$I_{p h}$ & Light current (I) & $I_{m p}$ & $\begin{array}{c}\text { Current at peak power point in reference } \\
\text { condition (A) }\end{array}$ \\
\hline$I_{D}$ & Diode current (A) & $V_{m p}$ & $\begin{array}{l}\text { Voltage at peak power in } \\
\text { reference condition }(\mathrm{V})\end{array}$ \\
\hline$I_{s h}$ & Shunt current (A) & $I_{p h, r e f}$ & Reference light current (A) \\
\hline$I_{o}$ & $\begin{array}{l}\text { Saturation current } \\
\text { of the diode (A) }\end{array}$ & $G$ & Irradiance $\left(\mathrm{W} / \mathrm{m}^{2}\right)$ \\
\hline$I_{o, \text { ref }}$ & $\begin{array}{l}\text { The reverse saturation } \\
\text { current }(\mathrm{A})\end{array}$ & $G_{\text {ref }}$ & Irradiance at reference condition $\left(\mathrm{W} / \mathrm{m}^{2}\right)$ \\
\hline$I_{s c}$ & Short circuit current (A) & $n$ & Ideality factor of the diode \\
\hline$V_{o c}$ & Open circuit voltage $(\mathrm{V})$ & $N$ & Number of cells in series \\
\hline$\mu_{I_{s c}}$ & $\begin{array}{l}\text { Temperature coefficient of } \\
\text { short-circuit current }(\mathrm{A} / \mathrm{K})\end{array}$ & $k$ & Boltzmann constant $\left(1.38 \times 10^{-23} \mathrm{~J} / \mathrm{K}\right)$ \\
\hline$q$ & $\begin{array}{l}\text { Electron charge } \\
\left(1.6 \times 10^{-19} \text { coulomb }\right)\end{array}$ & $R_{s h}$ & Shunt resistance $(\Omega)$ \\
\hline$R_{s}$ & $\begin{array}{l}\text { Series resistance of } \\
\text { generator }(\Omega)\end{array}$ & $E_{g}$ & Gap Energy (for the silicon $E_{g}=1.12 \mathrm{eV}$ ) \\
\hline
\end{tabular}

